\title{
EM TORNO DA MEMÓRIA E DO TESTEMUNHO
}

O dossiê especial "Em torno da memória e do testemunho", da Revista Eletrônica Literatura e Autoritarismo, reúne artigos que abordam aspectos conceituais com enfoque na relevância da memória e do testemunho dentro dos processos de construção do passado no presente.

No primeiro artigo do dossiê, intitulado "A instabilidade do ser e do objeto: uma análise de Sea Without Shore", as autoras Ana Elisa de Oliveira Medrado Drawin e Marina Ribeiro Mattar analisam o filme Sea Without Shore, dirigido por André Semenza e Fernanda Lippi, enfocando o ponto de tangência entre as imagens que emergem da natureza e as noções de melancolia, trauma, memória e amor. A protagonista, uma mulher, que sofre a dor da perda de sua amada, se encontra em uma ilha sueca no século XIX. O lirismo do filme se constrói também pelo procedimento estético de leitura em voz off de poemas de Charles Swinburne e Renée Vivien, associada à sequência imagética de diversas paisagens.

Em "Livre, nasce o livro: reflexões sobre a ficcionalidade da memória da barbárie a partir de Uma menina está perdida no seu século à procura do pai, de Gonçalo M. Tavares", Constance von Krüger propõe a análise do texto ficcional a partir de um escopo teórico que integra o conceito de catástrofe, no sentido empregado por Walter Benjamin, a aporia sobre a escrita de poesia após Auschwitz, postulada por Theodor Adorno, bem como a potência do ineditismo como forma de resistência, de acordo com a formulação de Hanna Arendt, no intuito de reconhecer a memória da barbárie como potência ética e estética na contemporaneidade.

No artigo "Entre a memória e o exílio: uma leitura de Bartolomeu Campos Queirós, Christian Victor de Oliveira Coelho e Rafael Vinicius da Fonseca Pereira elegem obras do escritor Bartolomeu Campos Queirós para estudo, tomando como aspectos centrais para a construção do texto literário a memória e o exílio. Segundo os autores, a escrita literária de Bartolomeu Campos Queirós é marcada pela articulação entre elementos autobiográficos e ficcionais, num entrelaçamento das memórias de infância com a fantasia. A temática do exílio também se faz presente nas obras, em que a experiência negativa, para além de sua dimensão concreta e de seus efeitos simbólicos, é ressignificada esteticamente.

Em "Houve uma revolução a leste de Bucareste? Um olhar cinematográfico sobre o fim do regime Ceausescu", Fábio Ávila Arcanjo elege como corpus de análise a produção fílmica romena A leste de Bucareste (2005), do cineasta Corneliu Porumboiu. A partir de fundamentação teórica em torno da enunciação, proposta por Patrick Charaudeau e José Luis Fiorin, além do conceito de revolução segundo a definição proposta por Hanna Arendt, e o conceito de memória, de acordo com as definições propostas por Maurice Halbwachs e Michael Pollak, Fábio Ávila Arcanjo conjuga os postulados teóricos a fim de evidenciar a importância do processo de rememoração e a dinâmica existente entre a memória individual e a memória coletiva. 
O artigo "The Invisibility of 19th Century African American (Auto)Biographies", de Hanna Karolyne Souza Simões e Marcel de Lima Santos, objetiva investigar como as experiências de escravidão de afro-americanos foram desconsideradas como traumáticas e indaga por que seus escritos (auto)biográficos foram relegados a uma posição marginalizada na área acadêmica. Para isso, a análise baseia-se na relação entre memória, identidade e (auto)biografia, elegendo como corpus as obras Incidents in the Life of a Slave Girl (1861), de Harriet Ann Jacobs, e Plantation Memories: Episodes of Everyday Racism (2008), de Grada Kilomba.

Em "Lembranças de mulheres em armas: relatos memorialísticos sobre o front", Joyce Rodrigues Silva Gonçalves faz uma análise do livro A guerra não tem rosto de mulher, da escritora bielorrussa Svetlana Aleksièvitch, adotando a perspectiva dos estudos sobre o testemunho e suas relações com a memória, além de considerar as questões de gênero presentes na obra. Para isso, a autora pontua também algumas problemáticas inerentes às narrativas de memória, como a lembrança, o esquecimento, o silenciamento, a autoria, a ficção e as experiências vividas.

No artigo "Em primeira(s) pessoa(s): a memória individual no contexto da África e na perspectiva de Ngũgĩ wa Thiong'o”, os autores Marcelo França Marques Cândido e Bernardo Nascimento de Amorim problematizam algumas constatações acerca do uso excessivo da primeira pessoa na literatura contemporânea, que seria responsável por uma possível crise da ficção. As experiências traumáticas do século XX implicaram intersecções entre o universo literário e o discurso memorialístico. Para o enfoque da experiência africana, os autores elegem a obra Sonhos em tempo de guerra, primeiro volume da trilogia autobiográfica de Ngũgĩ wa Thiong'o, afirmando a literatura como espaço possível de reconstrução do sujeito fragmentado a partir do relato autobiográfico.

Por sua vez, o artigo "Collective Memory and Cultural Trauma in Female-Authored African American Life Narratives”, de Michelle Santos Gontijo e Thomas LaBorie Burns, propõe a análise das obras Incidents in the Life of a Slave Girl (1861), narrativa de Harriet Ann Jacobs, e Reminiscences of My Life in Camp with the 33rd United States Colored Troops Late 1st S. C. (1902), relato memorialístico da Guerra Civil norte-americana, de Susie King Taylor, enfocando o estudo da relação entre memória coletiva e escravidão como trauma cultural na literatura de narrativa feminina enquanto "memórias subterrâneas", conforme postulado por Michael Pollak.

Em “O esquecimento apresentado em 'O feminino e o sagrado', de Julia Kristeva e Catherine Clément, como parte da construção da identidade feminina”, Tatiana Leal Paula Bernardes e Leandro Garcia Rodrigues refletem sobre o esquecimento em relação às posições femininas na sociedade frente àqueles que detêm o poder da determinação, por exemplo, da "memória oficial". A análise da obra O feminino e o sagrado, de Julia Kristeva e Catherine Clément, possibilita aos autores pensar de maneira crítica sobre o conceito de "memória", que, na visão de Maurice Halbwachs, se constrói coletivamente, podendo ser base para a formação identitária de determinado grupo ou sociedade, mas também ser parte do exercício do poder de exclusão, por exemplo, de mulheres que estejam à margem e são, assim silenciadas através de políticas de esquecimento. 
Por fim, no artigo "A representação mimética e a literatura de testemunho em Primo Levi", Valdirene Edna Ferreira Conrado e Volker Karl Lothar Jaeckel fazem uma análise de alguns relatos testemunhais de Primo Levi, sobrevivente do campo de extermínio de Auschwitz, lidos à luz do conceito de mimesis, a fim de atestar a importância do discurso testemunhal como ferramenta de verificação de determinado fato histórico, no caso, da Shoah.

Desejamos a todas e a todos uma ótima leitura!

Os Organizadores Elcio Loureiro Cornelsen Rosani Ketzer Umbach 
